\title{
NEPHRON SPARING SURGERY IN RENAL CANCER - INDIVIDUAL DECISION OR STANDARD PROCEDURE?
}

\author{
BERND J. SCHMITZ-DRÄGER(1), BIRGIT BEICHE(1), CLAUS FISCHER ${ }^{(2)}$, \\ FELIKSAS JANKEVICIUS ${ }^{(3)}$, THOMAS EBERT ${ }^{(1)}$ \\ ${ }^{(1)}$ Urologie, EuromedClinic. Fürth, Germany. ${ }^{(2)}$ Urologische Klinik. Bayreuth, Germany. \\ ${ }^{(3)}$ Dept. of Urology, Lithuanian Oncology Center. Vilnius, Lithuania.
}

Actas Urol Esp. 27 (1): 10-17, 2003

\section{RESUMEN}

\section{CIRUGÍA CONSERVADORA DE LA NEFRONA EN EL CÁNCER DE RIÑÓN - ¿DECISIÓN INDIVIDUAL O PROCEDIMIENTO NORMALIZADO?}

A lo largo de la última década, la cirugía conservadora del órgano ha alcanzado reconocimiento generalizado dentro de la comunidad urológica internacional. En consecuencia, la cuestión de la cirugía radical frente a la cirugía conservadora del órgano está siendo cada vez más debatida de forma polémica. A día de hoy, incluso los defensores de la nefrectomía radical deben admitir que los resultados a largo plazo obtenidos con la cirugía conservadora de la nefrona son excelentes. Por consiguiente, la heminefrectomía se ha convertido en un tratamiento habitual en pacientes con función renal comprometida. Sin embargo, en pacientes cuyo riñón contralateral es normal, las directrices nacionales e internacionales siguen mostrándose favorables a la nefrectomía radical. El aumento de la morbilidad y las dudas sobre la eficacia de la heminefrectomía en relación con el control tumoral son los motivos clave tras esta estrategia. Como parte de este análisis, los autores destacan la hipótesis de que las diferencias actuales entre cirugía conservadora del órgano y nefrectomía radical en relación con la supervivencia son marginales siempre que se cumplan los requisitos para la heminefrectomía. Así pues, la polémica actual parece basarse sobre todo en suposiciones y convicciones más que en hechos reales. Para responder definitivamente a esta pregunta se ha sugerido la realización de un ensayo clínico prospectivo y aleatorizado, aunque sin subestimar los problemas que conlleva dicho estudio.

PALABRAS CLAVE: Cáncer de riñón. Heminefrectomía. Preservación del órgano.

\begin{abstract}
“NEPHRON SPARING SURGERY IN RENAL CANCER - INDIVIDUAL DECISION OR STANDARD PROCEDURE?”

Organ-preserving surgery has gained widespread acceptance within the international urological community through the last decade. In consequence, the question of radical vs. nephron sparing surgery for the treatment of renal cancer is increasingly discussed in a controversial way. Today, even advocates of a radical nephrectomy must admit that long-term results obtained through nephron sparing surgery are excellent. In consequence, heminephrectomy has become a standard treatment in patients with impaired renal function. However, in patients with a normal contralateral kidney, national and international guidelines still favor radical nephrectomy. An increased morbidity and doubts on the efficacy of heminephrectomy concerning tumor control are the key reasons behind this strategy. Within this analysis the authors stress the hypothesis that the actual differences between organ-preserving surgery and radical nephrectomy concerning survival are marginal if the requirements for heminephrectomy are met. Therefore, the actual controversy appears to be rather based upon assumptions and convictions than on actual facts. To definitively answer this question a prospective randomized trial is suggested, however, the problems of this study may not be underestimated.
\end{abstract}


$\mathrm{N}$ ephron sparing surgery has been performed occasionally since the early 1950ies, when Vermooten ${ }^{1}$ first reported on a heminephrectomy in a patient with renal cancer. However, it took nearly 40 years until Novick et al. ${ }^{2}$, Petritsch et al. ${ }^{3}$ and Steinbach et al. ${ }^{4}$ reported on long-term results of this procedure in larger patient series. Since these initial reports the excellent results obtained have been confirmed by other groups or updated data ${ }^{5,6}$. Although data from prospective randomized trials have not been presented so far, nephron sparing surgery for renal cancer has gained widespread acceptance among the international urological community.

This contrasts to a relative reluctance concerning this procedure in national or international guidelines recommending to perform nephron sparing surgery in patients with normal contralateral kidney only in selected cases with peripheral tumors of less than $4 \mathrm{~cm}$ diameter a good patient compliance and after profound information of the patient ${ }^{7}$. For patients with impaired renal function an "individual procedure" is recommended.

In this manuscript we would like to exploit the current literature the different aspects of nephron sparing surgery in renal cancer.

\section{LOCAL CONTROL}

In general, different surgical approaches for organ-preserving surgery in renal cancer are conceivable. However, tumor enucleation along the pseudocapsule harbours a significant risk of positive margins as shown by ex vivo studies by Blackley et al. ${ }^{8}$ and Rosenthal et al. ${ }^{9}$ and, thus, is currently considered as obsolete. Today, tumor resection together with 0.5 to $1 \mathrm{~cm}$ normal appearing renal tissue and the adherent perirenal fat (Gerota fascia) (e.g. heminephrectomy or pole resection) represents the surgical standard. Following these recommendations, positive margins are a rare event. Lee and coworkers (2000) reported on positive margins in 1 out of 79 patients (1.3\%) undergoing nephron-sparing surgery for renal cancer.

With regard to the upper limits of tumor size suitable for organ preserving surgery development of distant metastasis and disease-specific survival may be considered as primary endpoints.
Opponents of organ-preserving surgery in renal cancer emphasize the significant risk of local tumor recurrence originating from additional tumor foci in the remaining part of the kidney. And indeed, systematic pathohistological examinations of kidneys with renal cancer yielded an incidence of 12 - 20\% additional tumor foci in morphologically normal appearing parts of the organ (Blackley et al. ${ }^{8}$, Mukamel et al. ${ }^{9}$, Schlichter et al. ${ }^{10}$ ). Furthermore, these foci remain undetectable even with modern imaging modalities (Schlichter et al. ${ }^{11}$ ).

However, this high incidence contrasts with an actual local recurrence rate of less than $10 \%$ in most major series with long-term follow-up (Novick et al. ${ }^{2}$, Petritsch et al. ${ }^{3}$ and Steinbach et al. ${ }^{4}$ ) (Table I). Therefore, the biological significance of those additional tumor foci in the residual part of the kidney remains unclear. Based upon those considerations, local tumor control after removal of small tumor lesions is good, however, comprises an appr. 10\% risk for local tumor recurrence.

\section{METASTASES}

Apart from local tumor control the question of a different outcome for nephron-sparing surgery in renal cancer concerning tumor progression, metastasis and death of disease remain of key relevance. An impaired outcome after heminephrectomy could be related to either a lack of detecting lymph node metastases during surgery, which, subsequently would result in metastasation and death. Furthermore, development of metastases from recurrent tumors in the remaining parts of the kidney might be another risk for the patients.

\section{LYMPH NODE METASTASES}

Lymph node dissection is not routineously performed during heminephrectomy. The reasons for this are two-fold. First, the incidence of lymph node metastases in small renal tumors, the common target of organ preserving surgery, is very low. Miller et al. (1999) observed no lymph node metastases in those patients with tumors less than 2.5 $\mathrm{cm}$ in diameter, while small tumors between 2.5$4 \mathrm{~cm}$ already had lymph node metastases in 6.9\% of the cases. The results of the prospective, randomized EORTC trial 30881 demonstrated lymph 
BERND J. SCHMITZ-DRÄGER, BIRGIT BEICHE, CLAUS FISCHER, Y COLS.

TABLE I

RESULT OF ORGAN-PRESERVING SURGERY FOR RENAL CANCER (SELECTED PUBLICATIONS)

\begin{tabular}{|c|c|c|c|c|c|c|}
\hline Author (year) & $\begin{array}{l}\text { Patients } \\
\text { (n) }\end{array}$ & $\begin{array}{c}\text { Median/ mean } \\
\text { follow-up } \\
\text { [months] (range) }\end{array}$ & $\begin{array}{l}\text { Local tumor } \\
\text { recurrence (\%) }\end{array}$ & $\begin{array}{c}\text { Distant } \\
\text { metastases (\%) }\end{array}$ & $\begin{array}{l}\text { 5-year survival } \\
\text { rate (\%) } \\
\text { DSS/ OS }\end{array}$ & $\begin{array}{c}\text { 10-year survival } \\
\text { rate (\%) } \\
\text { DSS/ OS }\end{array}$ \\
\hline Butler (1995) & $\begin{array}{c}46 \\
\text { (elective) }\end{array}$ & 48 & 2.1 & 0 & $\begin{array}{l}100 \\
\text { n.r. }\end{array}$ & \\
\hline Van Poppel (1998) & $\begin{array}{l}76 \text { (mostly } \\
\text { imperative) }\end{array}$ & $\begin{array}{c}75 \\
(3-156)\end{array}$ & 0 & 3.9 & & \\
\hline Hafez (1999) & 485 (elective) & 47 & 3.2 & 5.8 & $\begin{array}{l}92 \\
81\end{array}$ & $\begin{array}{l}80 \\
53\end{array}$ \\
\hline Lee et al. (2000) & $\begin{array}{c}79 \text { (52\% } \\
\text { imperative) }\end{array}$ & $\begin{array}{c}40 \\
(0.1-105)\end{array}$ & 0 & 4.5 & $\begin{array}{l}95 \\
87\end{array}$ & \\
\hline Fryczkowski (2000) & $\begin{array}{c}53 \\
\text { (elective) }\end{array}$ & $\begin{array}{c}63.8 \\
(20-143)\end{array}$ & 5.7 & 1.9 & & $\begin{array}{c}98 \\
\text { n.r. }\end{array}$ \\
\hline Fergany (2000) & $\begin{array}{c}107 \\
\text { (imperative; } \\
50 \%>\mathrm{T} 1 \text { ) }\end{array}$ & $\begin{array}{c}104 \\
(4-255)\end{array}$ & 10 & 28 & $\begin{array}{c}88.2 \\
77\end{array}$ & $\begin{array}{l}73 \\
45\end{array}$ \\
\hline Herring (2001) & 65 & $\begin{array}{c}79.5 \\
(0.7-205)\end{array}$ & 35 (hereditary) & 0 & 100 & \\
\hline
\end{tabular}

node metastases in only $3.3 \%$ of 336 patients with renal tumors (clinical stage $\mathrm{T} 1$ ) that were judged to be free of metastases in preoperative staging (Blom et al. 1999). Based upon those observations a frequency of less than $5 \%$ in tumors even up to $7 \mathrm{~cm}$ in diameter appears to reflect a reasonable estimation for the risk of lymph node metastases in this group of patients. This is in line with results reported by Minervini et al. (2001) suggesting a $2 \%$ incidence of lymph node metastases in 49 patients without enlarged lymph nodes judged either by preoperative tumor staging or during surgery.

A second argument may be that the benefit from lymph node dissection is unclear and, thus has remained a matter of controversial discussion until today. Numerous retrospective reports have been published through the last years. Minervini et al. (2001) did not observe different 5-year-survival rates in 167 patients undergoing either radical tumor nephrectomy alone or in combination with extensive lymph node dissection. These findings are in line with previous reports by Bassil et al. (1985) and Golimbu et al. (1986). In contrast, observations by Schafhauser et al. (1999) in more than 1000 patients with renal cancer suggest a survival benefit for patients after extensive lymph node dissection. However, the lack of a prospective design and, thus, undefined selection criteria limit the impact of these retrospective findings.

Recently, preliminary data of the EORTC trial 30881 have been reported by Mickisch et al. (1999). In this prospective, randomized study including more than 700 patients no survival benefit for patients undergoing extensive lymph node dissection as compared with patients after radical tumor nephrectomy only has been observed. These findings clearly demonstrate that a potential benefit of therapeutic lymph node dissection is limited to a very small number of patients. It may be notable, however, that extensive lymph node dissection had no impact on the morbidity of the procedure.

In summary, provided no evidence of enlarged lymph nodes at preoperative tumor staging, the probability of lymph node metastases in small renal tumors is very low. Furthermore, the potential benefit originating from extensive lymph node dissection is definitively limited, thus, making the necessity of lymph node dissection during organ preserving surgery more than questionable. 


\section{DISTANT METASTASES AND SURVIVAL}

Even advocates of nephron sparing surgery in renal cancer must admit that the results with regard to tumor control may come close but can not exceed those obtained by standard nephrectomy. In consequence, it must be questioned if the differences are significant and if potential advantages resulting from organ preserving surgery justify a change of current standards.

Today, long-term results on nephron sparing surgery have been published and, thus, provide some impressions on the efficacy of this procedure. Recently, Fergany et al. (2000) reported survival data of 107 patients having nephron sparing surgery for renal cancer before 1988. The 5- and 10 -year disease specific survival was $88.2 \%$ and $73 \%$ respectively and is, therefore, similar to reports on survival after radical tumor nephrectomy. Most notable is the fact that appr. 90\% of the patients in the Cleveland series had either a functional impairment or previously lost the contralateral kidney.

In another series including 49 patients with hereditary renal cancer undergoing 71 surgical procedures for renal cancer between 1988 to 1998. In 65 cases, organ preserving procedures were performed. After a median follow-up interval of 79.5 months, local tumor recurrence was observed in $35 \%$ of the patients. Only one patient in this malselected series developed distant metastases after more than 6.5 years.

Until today, prospective, randomized trials comparing organ preserving surgery and radical nephrectomy are lacking. Therefore, only indirect comparison is available to investigate this crucial question. In a non-randomized study on 252 patients with tumors of less than $4 \mathrm{~cm}$ diameter. Lee and coworkers (2000) observed no differences concerning disease-specific survival, tumor-free survival or crude survival for a 3-year follow-up period. Applying a similar study design on 88 patients with tumors of less than $4 \mathrm{~cm}$ diameter. Butler and coworkers (1995) reported no differences concerning tumor-specific survival after 5 year follow-up.

Lau and coworkers (2000) compared 164 patients after radical nephrectomy and another 164 patients after nephron-sparing surgery in a matched-pair analysis. They reported a significant difference concerning local recurrence in favor of the nephrectomy group $(0.8 \%$ vs. $5.4 \%$, respectively). However, 10-year results regarding crude survival and disease- specific survival were not different between the two groups. These results are supported by findings of Belldegrun et al. (1999) in a matched-pair analysis including 271 patients. For a 57-months follow-up interval cancer-specific survival was not different in T1 renal cancer (TNM 1997 Classification) after radical nephrectomy or nephron-sparing surgery. Only in patients with $\mathrm{T} 2$ renal cancer radical nephrectomy proved to be superior compared with heminephrectomy.

Summarizing the actual state-of-knowledge there is some evidence that, at least in patients with tumors less than $4 \mathrm{~cm}$ in diameter, survival after partial nephrectomy is not impaired despite a greater amount of local tumor recurrences. This, however, highlights the relevance of a good patient compliance if nephron sparing surgery is considered.

\section{COMPLICATIONS AND BENEFIT}

In general, perioperative morbidity and mortality after organ preserving surgery are not higher than after radical nephrectomy (Corman et al. 2000). However, significant blood loss still represents a problem of heminephrectomy (Herring et al. 2001). This conclusion is in line with the observations in a retrospective comparison between organ preserving surgery and radical nephrectomy in 211 patients by Shvarts et al. (2000). Average Blood loss in the heminephrectomy group was 550 cc and, thus, more than twice as high as in the patients after radical nephrectomy. The reason for these observations is parenchymal bleeding during dissection of the kidney. Technical improvements, however, are likely to make up for this problem. The development and use of ultrasound or the water-jet-scalpel (Basting et al. 2000) will significantly decrease blood loss during parenchymal incisions in organ preserving procedures in the future.

The question for putative benefits of nephron sparing surgery certainly deserve a critical analysis. There is unanimous agreement on the role of organ sparing surgery in patients after kidney removal or with chronic renal failure. Even in patients with conditions with a potential impact 
on renal function (Multiple renal cysts, significant vascular diseases (e.g. diabetes)) the necessity of preserving renal function is obvious. However, the question of a benefit of heminephrectomy for patients with normal contralateral kidney remains a matter of controversy. Maintenance of kidney function and avoiding hemodialysis might be strong arguments favoring a nephron sparing procedure.

Several reports permit the estimation of the risk of metachronous renal cancer after tumor nephrectomy (Table II). Based upon these publications the risk for tumor development in the remaining kidney is appr. $1 \%$. Although the interval between the initial tumor nephrectomy and the diagnosis of a contralateral tumor may exceed several years early detection of the secondary tumor by ultrasound may still permit organ preserving surgery and, thus, avoiding chronic hemodialysis in at least some of these patients.

\section{TABLA II}

METACHRONOUS RENAL CANCER IN THE SOLITARY KIDNEY AFTER TUMOR NEPHRECTOMY

\begin{tabular}{|l|c|c|}
\hline Author (year) & $\mathbf{n}$ & $\begin{array}{c}\text { Metachronous } \\
\text { tumors (\%) }\end{array}$ \\
\hline Johnson et al. (1977) & 709 & 4 \\
\hline Viets et al. (1977) & 236 & 4 \\
\hline Vermillion et al. (1972) & 329 & 4 \\
\hline Sparwasser et al. (1984) & 369 & 2 \\
\hline Lau et al. (2000) & 1.492 & 2 \\
\hline Total & $\mathbf{3 . 1 3 5}$ & $\mathbf{2 7}$ (0.9) \\
\hline
\end{tabular}

Considering the fact that renal cancer mainly occurs in the $6^{\text {th }}$ or $7^{\text {th }}$ decade of life the risk for loosing the function of a remaining normal contralateral kidney is low. Although precise figures are lacking, it appears reasonable to anticipate that less than $1 \%$ of the patients with normal kidney function after radical nephrectomy will develop end stage renal failure due to non-malignant conditions (trauma, hypertension, diabetes). This may be confirmed by a retrospective analysis by Grossman et al. (1994) who studied creatinine levels in 109 consecutive patients 15-25 years after tumor nephrectomy. Only one patient developed end-stage renal failure. This is in contrast with the findings of Lau et al. (2000) observing creatinine levels exceeding $2.0 \mathrm{mg} / \mathrm{dL}$ significantly more frequently after radical nephrectomy as compared to organ preserving surgery ( $22.4 \%$ vs. $11.6 \%$ ) in a matched-pair analysis in 328 patients.

The problem of unnecessary nephrectomy due to a benign condition has rarely been addressed. Specificity of CT-scan and MRI has been reported to range between 96-98\% (Zagoria et al. 1990, Schunk et al. 1994). However, in several of these publications tumor entities of doubtful malignant potential (angiomyolipoma or oncocytoma) were considered as renal cancer. Therefore, the risk of an unnecessary nephrectomy presumably ranges between $4-8 \%$.

Another interesting aspect was addressed by Clark et al. (2001) investigating the impact of renal function after surgery for renal cancer and quality of life. In this series, quality of life was superior in patients after nephron sparing surgery as opposed to another group after radical nephrectomy.

In summary, the chance of sparing patients from chronic hemodialysis by nephron sparing surgery is marginal. Only $1-2 \%$ of all patients may benefit in this regard from heminephrectomy. However, the impact of preserving renal function on quality of life certainly deserves further investigation.

\section{TECHNICAL ASPECTS}

Through the last 2 decades nephron sparing surgery has been technically refined and today standards to conduct this intervention have been defined. Because of the high risk of positive margins, tumor enucleation has been abandoned today and has been replaced by a resection of the tumor within a 0.5 to $1.0 \mathrm{~cm}$ layer of macroscopically normal appearing tissue. This procedure results in a remarkable low frequency of positive margins after organ preserving surgery of appr. 1$2 \%$ (Lee et al. 2000). For peripheral tumors the complete resection of the tumor together with the adhering tissue of Gerota's fascia is mandatory. Immediate examination of frozen sections by a pathologist to examine the margins of the specimen is routineously performed in most major institutions. In case of positive margins the organ sparing procedure in converted into radical nephrectomy. 
In small peripheral tumors preparation of the renal vessels is no longer performed, however, temporary occlusion of the renal vessels is of value in larger peripheral lesions or in central tumors (Hafez et al. 1998). If a longer interval of vessel occlusion is anticipated organ protection using tissue protecting solutions is advisable and, with regard to the preservation of renal function, superior to local cooling (Blech et al. 1988).

Recent reports demonstrate that removal of centrally located small renal tumors is technically feasible and safe (Hafez et al. 1998, Black et al. 2000). In consequence, ex-vivo surgery and autotransplantation are reserved for very rare cases.

\section{LAPARASCOPIC HEMINEPHRECTOMY}

Although laparascopic radical nephrectomy is considered a new standard procedure in the treatment of renal cancer by several urologic surgeons, only few reports on laparascopic nephron sparing surgery have been presented until today. The high risk of uncontrollable bleeding while dissecting the renal parenchyma is the key reason for this reluctance. The development of modern ultrasound dissection devices (e.g. Ultracision ${ }^{\circledR}$ ) has been prerequisite in order to perfomr this procedure.

Gasman et al. (1996) were the first to report on a laparascopic heminephrectomy. More recently, Janetschek et al. (1998) published on a series of 7 patients successfully undergoing this intervention. Rassweiler et al. (2000) summarized the results of 53 patients from 4 major European centers. These results suggest that laparascopic heminephrectomy is obviously correlated with greater blood losses and a longer time of surgery as compared to laparascopic radical nephrectomy. In 6 cases (11\%) reintervention was required, mostly due to urinary leakage. Secondary, open nephrectomy was performed in 2 patients. Average hospital time was 5.4 days and, thus, probably longer if compared to laparascopic radical nephrectomy, however, still shorter than after open nephrectomy.

\section{CONCLUSIONS}

Since the initial results on a systematical evaluation of organ preserving surgery for treatment of renal cancer in the late 1980ies this approach has actually become a routine procedure. The technique has been developed and standardized and today, open nephron sparing surgery can be considered a safe procedure. In consequence, most national and international guidelines consider this procedure an option in patients with impaired renal function or in patients with renal cancer in a solitary kidney.

Laparascopic heminephrectomy appears to be an interesting variation of the theme, however, must be considered as highly experimental at this stage.

Despite its widespread acceptance nephron sparing surgery is not yet accepted as a standard in patients with normal contralateral kidney. The arguments for this concept may be sought in higher blood losses and a slightly higher overall morbidity if trials comparing nephron sparing surgery and radical nephrectomy in matched-pair analyses are considered. Furthermore, from a theoretical point of view, tumor control through organ preserving surgery may produce results equal to radical nephrectomy only under optimal circumstances, but is likely to be less effective in every-day routine. These disadvantages may be balanced by a potential benefit in patients that will, subsequently, loose renal function for a variety of reasons. However, as demonstrated in larger series, this risk is very small. The impact of preservation of renal function on quality of life or the health status of an aging population is unclear and requires further investigation.

While the impact of follow-up examinations in patients after radical nephrectomy remain a matter of controversial discussion, specifically local tumor control is important in patients after nephron sparing surgery. Long-term results have demonstrated that local tumor recurrence does not occur before 48 months in $=\mathrm{T} 2$ tumors (Hafez et al. 1997). Consideration of this fact is of relevance for adequate follow-up in patients after heminephrectomy and underlines the impact of patient compliance.

Based upon these considerations, the authors believe that the differences between organ sparing procedure and radical nephrectomy in patients with normal contralateral kidney are marginal provided some requirements are met:

- Good patient compliance. 
- Frozen section examination with clearly negative surgical margins.

- Small (peripheral) tumor.

- Experience in nephron sparing surgery.

From this analysis it becomes apparent that at this stage the time has come to further address this question within a prospective randomized trial. The crucial problem of this type of study is, however, that the small putative differences between the two concepts require a great study population and, furthermore, will only become visible after a very long follow-up interval thus impeding the chances to find a valid answer to the question of this manuscript.

\section{REFERENCES}

1. VERMOOTEN V.: Indications for conservative surgery in certain renal tumors: a study based on the growth pattern of the clear cell carcinoma. J Urol 1950; 64: 200-208.

2. NOVICK AC, STREEM S, MONTIE JE, PONTES JE, SIEGEL S, MONTAGUE DK, GOORMASTIC M.: Conservative surgery for renal cell carcinoma: a single-center experience with 100 patients. J Urol 1989; 141: 835-839.

3. PETRITSCH PH, RAUCHENWALD M, ZECHNER O, LUDVIG W, PUMMER K, URLESBERGER H, EBERLE J, JOOST H, KAUFMAN F, KUGLER W, DECRISTOFORO A, DITTEL E.: Results after organ -preserving surgery for renal cell carcinoma. Eur Urol 1990; 18: $84-87$.

4. STEINBACH F, THÜROFF JW, STÖCKLE M, FURRER A, RIEDMILLER H, KIEWEL R, HOHENFELLNER R.: Organerhaltende Chirurgie des Nierenzellkarzinoms. Dtsch Med Wschr 1991; 116: 121-127.

5. VAN POPPEL H, BAMELIS B, OYEN R, BAERT L.: Partial nephrectomy for renal cell carcinoma can achieve long-term tumor control. J Urol 1998 sep; 160 (3 Pt 1): 674-678.

6. FERGANY AF, HAFEZ KS, NOVICK AC.: Long-term results of nephron sparing surgery for localized renal cell carcinoma: 10-year followup. J Urol 2000 feb; 163 (2): 442-445.

7. MICKISCH G, CARBALLIDO J, HELLSTEN S, SCHULZE H, MENSINK H.: Guidelines on renal cell cancer. Eur Urol 2001; 40: 252-255.

8. BLACKLEY SK, LAGADA L, WOOLFITT RA, SCHELLHAMMER PF.: Ex situ study of the effectiveness of enucleation in patients with renal cell carcinoma. J Urol 1988; 140: 6-10.

9. ROSENTHAL CL, KRAFT R, ZINGG EJ.: Organ-preserving surgery in renal cell carcinoma: tumor enucleation versus partial kidney resection. Eur Urol 1984; 10: 222-228.

10. SCHLICHTER A, WUNDERLICH H, JUNKER K, KOSMEHL H, ZERMANN DH, SCHUBERT J.: Where are the limits of elective nephron- sparing surgery in renal cell carcinoma? Eur Urol 2000; 37: 517-520.
11. MUKAMEL E, KONICHEZKY M, ENGELSTEIN D, SERVADIO C.: Incidental small renal tumors accompanying clinically overt renal cell carcinoma. J Urol 1988; 140: 22-24.

12. SCHLICHTER A, SCHUBERT R, WERNER W, ZERMANN DH, SCHUBERT J.: How accurate is diagnostic imaging in determination of size and multifocality of renal cell carcinoma as a prerequisite for nephron-sparing surgery? Urol Int 2000; 64: 192197.

13. LEE CT, KATZ J, SHI W, THALER HT, REUTER VE, RUSSO P.: Surgical management of renal tumors 4 cm or less in a contemporary cohort. J Urol 2000; 163 (3): 730-736.

14. MINERVINI A, LILAS L, MORELLI G, TRAVERSI C, BATTAGLIA S, CRISTOFANI R, MINERVINI R.: Regional lymph node dissection in the treatment of renal cell carcinoma: is it useful in patients with no suspected adenopathy before or during surgery? BJU Int 2001; 88: 169-172.

15. MILLER J, FISCHER C, FREESE R, ALTMANNSBERGER M, WEIDNER W.: Nephron-sparing surgery for renal cell carcinoma-is tumor size a suitable parameter for indication? Urology 1999; 54: 988993.

16. BLOM JH, VAN POPPEL H, MARECHAL JM et al.: Radical nephrectomy with and without lymph node dissection: preliminary results of the EORTC randomized phase III protocol 30881. EORTC Genitourinary Group. Eur Urol 1999; 36: 570-575.

17. SCHAFHAUSER W, EBERT A, BROD J, PETSCH S, SCHROTT KM.: Lymph node involvement in renal cell carcinoma and survival chance by systematic lymphadenectomy. Anticancer Res 1999; 19: 1.5731.578 .

18. BASSIL B, DOSORETZ DE, PROUT GR Jr: Validation of the tumor, nodes and metastasis classification of renal cell carcinoma. $J$ Urol 1985; 134: 450-454.

19. GOLIMBU M, AL-ASKARI S, TESSLER A, MORALES P.: Aggressive treatment of metastatic renal cancer. J Urol 1986; 136: 805-807.

20. MICKISCH GH.: Lymphatic metastases in renal cell carcinoma. What is the value of operation and adjuvant therapy?. Urologe A 1999; 38: 326-331.

21. WUNDERLICH H, SCHLICHTER A, REICHELT O, ZERMANN DH, JANITZKY V, KOSMEHL H, SCHUBERT J.: Real indications for adrenalectomy in renal cell carcinoma. Eur Urol 1999; 35: 272-276.

22. HERRING JC, ENQUIST EG, CHERNOFF A, LINEHAN WM, CHOYKE PL, WALTHER MM.: Parenchymal sparing surgery in patients with hereditary renal cell carcinoma: 10-year experience. J Urol 2001; 165: 777-781.

23. LAU WK, BLUTE ML, WEAVER AL, TORRES VE, ZINCKE H.: Matched comparison of radical nephrectomy vs nephron-sparing surgery in patients with unilateral renal cell carcinoma and a normal contralateral kidney. Mayo Clin Proc 2000; 75: 1.2361.242 .

24. CORMAN JM, PENSON DF, HUR K et al.: Comparison of complications after radical and partial nephrectomy: results from the National Veterans Administration Surgical Quality Improvement Program. BJU Int 2000; 86: 782-729. 
25. SHVARTS O, TSUI KH, SMITH RB, KERNION JB, BELLDEGRUN A.: Blood loss and the need for transfusion in patients who undergo partial or radical nephrectomy for renal cell carcinoma. J Urol 2000; 164: 1.160-1.163.

26. BASTING RF, CORVIN S, ANTWERPEN C, DJAKOVIC N, SCHMIDT D.: Use of water jet resection in renal surgery: early clinical experiences. Eur Urol 2000; 38: 104-107.

27. GROSSMAN HB, SOMMERFIELD D, KONNAK JW, BROMBERG J.: Long-term assessment of renal function following nephrectomy for stage I renal carcinoma. Br J Urol 1994; 74: 279-282.

28. CLARK PE, SCHOVER LR, UZZO RG, HAFEZ KS, RYBICKI LA, NOVICK AC.: Quality of life and psychological adaptation after surgical treatment for localised renal cell carcinoma: impact of the amount of remaining renal tissue. Urology 2001; 57: 252-256.

29. GASMAN D, SAINT F, BARTHELMY Y, ANTIPHON P, CHOPIN D, ABBOU CC.: Retroperitoneoscopy: a laparoscopic approach for adrenal and renal surgery. Urology 1996; 47: 801-806.

30. JANETSCHEK G, DAFFNER P, PESCHEL R, BARTSCH G.: Laparoscopic nephron sparing surgery for small renal cell carcinoma. J Urol 1998; 159: 1.152-1.155.

31. RASSWEILER JJ, ABBOU C, JANETSCHEK G, JESCHKE K.: Laparoscopic partial nephrectomy. The European experience. Urol Clin North Am 2000; 27: 721-736.

32. ZAGORIA RJ, DYER RB, WOLFMAN NT, HINN GC, CHEN YM.: Radiology in the diagnosis and staging of renal cell carcinoma. Crit Rev Diagn Imaging 1990; 31: 81-115.

33. SCHUNK K, SCHILD H, STRUNK H, ROPP G, FRITZ T, SCHWEDEN F.: Computerized tomography of kidney tumors. Aktuelle Radiol 1994 sep; 4 (5): 235-242.

34. JOHNSON DE, VON ESCHENBACH A, STERNBERG J.: Bilateral renal cell carcinoma. J Urol 1978; 119: 23-24.

35. VIETS DH, VAUGHAN ED Jr., HOWARDS SS.: Experience gained form the management of 9 cases of bilateral renal cell carcinoma. J Urol 1977; 118: 937-939.

36. VERMILLION CD, SKINNER DG, PFISTER RC.: Bilateral renal cell carcinoma. J Urol 1972; 108: 219-222.

37. SPARWASSER C, BACH D, SPARWASSER H, ALTWEIN JE.: Das bilaterale Hypernephrom. Akt Urol 1984; 15: 312-316.

38. BLECH M, KALLERHOFF M, KEHRER G, VON ROMATOWSKI HJ et al.: Klinische Anwendung der kardioplegischen Lösung HTK nach Bretschneider zur insitu Protektion der Niere. Urologe A 1988; 27: 44-48.
39. HAFEZ KS, NOVICK AC, BUTLER BP.: Management of small solitary unilateral renal cell carcinomas: impact of central versus peripheral tumor location. J Urol 1998; 159: 1.156-1.160.

40. BLACK P, FILIPAS D, FICHTNER J, HOHENFELLNER R, THÜROFF JW.: Nephron sparing surgery for central renal tumors: experience with 33 cases. $J$ Urol 2000; 163: 737-743.

41. GILL IS, MERANEY AM, SCHWEIZER DK, SAVAGE SS, HOBART MG, SUNG GT, NELSON D, NOVICK AC.: Laparoscopic radical nephrectomy in 100 patients: a single center experience from the United States. Cancer 2001; 92: 1.843-1.855.

42. GASMAN D, SAINT F, BARTHELMY Y, ANTIPHON P, CHOPIN D, ABBOU CC.: Retroperitoneoscopy: a laparoscopic approach for adrenal and renal surgery. Urology 1996; 47: 801-806.

43. JANETSCHEK G, DAFFNER P, PESCHEL R, BARTSCH G.: Laparoscopic nephron sparing surgery for small renal cell carcinoma. J Urol 1998; 159 (4): 1.152-1.155.

44. RASSWEILER JJ, ABBOU C, JANETSCHEK G, JESCHKE K.: Laparoscopic partial nephrectomy. The European experience. Urol Clin North Am 2000; 27: 721-736.

45. BUTLER BP, NOVICK AC, MILLER DP, CAMPBELL SA, LICHT MR.: Management of small unilateral renal cell carcinomas: radical versus nephron-sparing surgery. Urology 1995; 45: 34-40.

46. HAFEZ KS, FERGANY AF, NOVICK AC.: Nephron sparing surgery for localized renal cell carcinoma: impact of tumor size on patient survival, tumor recurrence and TNM staging. J Urol 1999; 162: 1.9301.933.

47. FRYCZKOWSKI M, POTYKA A, HUK J.: Evaluation of organ sparing surgery results in patients with kidney cancer in scheduled operations. Med Sci Monit 2000; 6: 1.098-1.103.

48. HAFEZ KS, NOVICK AC, CAMPBELL SC.: Patterns of tumor recurrence and guidelines for followup after nephron sparing surgery for sporadic renal cell carcinoma. J Urol 1997; 157: 2.067-2.070.

Dr. Bernd J. Schmitz-Dräger

Urologie, EuromedClinic

Europa-Allee 1

D-90763 Fürth, Germany

(Trabajo recibido el 25 julio de 2002) 